УДК 32

https://doi.org/10.34142/24130060.2020.20.1.12

\title{
ПРОБЛЕМА ПОЛІТИЧНОГО ПРОСТОРУ В НАУКОВІЙ ПАРАДИГМІ СУЧАСНОСТI
}

\author{
О. I. Кошкіна
}

Харківський національний університет будівництва і архітектури

\section{H. I. Moicecвa}

Харківський національний технічний університет сільського господарства імені Петра Василенка

Розглянуто основні проблеми конщептуалізації та необхідності переосмислення розуміння політичного простору в умовах сучасних трансформачійних процесів. Політичний простір показано як одну з проекцій політики на відносини, які складаються між різними суб'єктами з приводу розподілу влади. При иьому політичний простір виступає регулятором відносин груп та індивідів, областю взаємодій груп інтересів на перетині «горизонтальних» $i$ «вертикальних» відносин. Він являє собою відкриту $i$ нестійку систему, на функиіонування якої великий вплив здійснюють зовнішні фактори.

Ключові слова: політичний простір, політичний процес.

\section{ПРОБЛЕМА ПОЛИТИЧЕСКОГО ПРОСТРАНСТВА В ПАРАДИГМЕ СОВРЕМЕННОСТИ}

\section{О. И. Кошкина, Н. И. Моисеева}

Рассмотрены основные проблемы концептуализации и необходимости переосмысления понимания политического пространства в условиях современных трансформационных процессов. Политическое пространство рассматривается в качестве одной из проекций политики на отношения, складываюшиеся между различными субъектами по поводу распределения власти. При этом политическое пространство выступает регулятором отношений групп и индивидов, областью взаимодействий групп интересов на пересечении «горизонтальных» и «вертикальных» отношений. Оно представляет собой открытую и неустойчивую систему, на функиионирование которой большое влияние оказывают внешние факторы.

Ключевые слова: политическое пространство, политический процесс.

\section{THE PROBLEM OF POLITICAL SPACE IN THE SCIENTIFIC PARADIGM OF MODERNITY}

\section{O. Koshkina, N. Moiseeva}

The main problems of conceptualization and the need to rethink the understanding of political space in modern transformation processes are considered. Political space is shown as one of the projections of politics on the relations between different actors about the distribution of power. In this case, the political space acts as a regulator of relations between groups and individuals, the area of interaction of interest groups at the intersection of «horizontal» and 
«vertical» relations.

The transition from the class subjectivity of industrial society to the fragmented declassed subjectivity of post-industrialism and the resulting transformation of power relations justify the need for a new conceptualization of political space. Horizontal models of social communication, emerging in the new conditions, determine the primacy of individuals before the state in implementing institutional change, determining the appropriate parameters of political space and political competition of individuals, their access to political exchanges at different levels. The strengthening of the processes of politicization of the economic and socio-cultural space occurs in crisis situations of the functioning of social systems, which leads to the expansion of the boundaries of the political sphere. In turn, the depoliticization of political processes and phenomena characteristic of the period of stable development of society leads to the limitation of political space. The need to reorganize the space-field requires the expansion of the boundaries of the political world, the emergence of new institutions and organizations.

Thus, the new conceptualization of political space arises as a response to the need to maintain control over socio-political processes that cause the effect of emancipation of individuals in a situation of growing uncertainty.

Thus, the political space is an open and unstable system, the functioning of which is greatly influenced by external factors.

Key words: political space, political process.

Постановка проблеми. Категорія «політичний простір» є важливою для політичної науки, оскільки визначає субстанціональну основу політичної діяльності, середовище, в якому відбуваються політичні процеси. Однак загальнотеоретична постановка проблеми політичного простору на сьогоднішній день фактично відсутня. Тому дослідники бачать необхідність в оновленні методологічної бази для вивчення цього феномена, концептуалізації його сучасної форми, виявленні теоретичного змісту і розширенні методологічного потенціалу.

Аналіз актуальних досліджень. Поняття «політичний простір» широко використовується як дослідниками, так і публіцистами. Традиційно вивчення еволюції поняття «політичний простір» відбувається в контексті родового поняття «соціальний простір». Спочатку дослідники, перебуваючи під впливом фізикалістських тенденцій, не вкладали соціального змісту в поняття «соціальний простір», розглядаючи його виключно як займану соціумом частина фізичного простору. Однак, уже в період класичної соціології кінця ХІХ - першої половини XX ст. існувала група дослідників, які розглядали соціальний простір саме як соціальне явище, а не як соціальний вимір фізичного простору. Але при цьому інтерпретація поняття 
«соціальний простір» відбивало загальнонаукову тенденцію того часу, згідно 3 якою простір уявлявся як позбавлене динамізму «вмістилище речей». Соціальний простір розглядався як об’єктивна реальність, яка існує первинно і незалежно від суб'єктів, що займають його.

Також для даного періоду характерно уявлення про окремі простори 3 позиції соціологічного холізму, яка визнавала пріоритет загального над окремим аж до повного розчинення специфіки останнього. Оскільки сфери соціуму функціонально знаходяться в повній залежності від соціуму в цілому, то простором політичної діяльності є не частина, а весь соціальний простір в цілому (Denysenko, 2015).

У другій половині $\mathrm{XX}$ в. бере початок принципово новий етап в розвитку поняття соціального простору. Фокус його вивчення зміщується в бік окремих, видових понять соціального простору, в тому числі поняття політичного простору. Домінуючою тенденцією у визначенні соціального простору стає визнання його динамічності, мінливості, нерозривного зв'язку 3 часом і діяльністю його суб’єктів (Denysenko, 2010).

Питання про суб'єктивний чинник в політичному просторі і про роль політичного суб'єкта в ньому знаходило різні рішення. Якщо в період поширення об'єктивістських трактувань політичного простору панівною тенденцією було применшення суб'єктного чинника, то в пізньокласичний період роль суб'єкта значно зросла. Відповідно до традицій постструктуралізму дослідники визначають політичний простір як реальність, що виникає в результаті автономної діяльності політичних акторів і складається з відносин політичного актора та інших акторів і агентів суспільства (Voronianskyi, 2012). На перший план виходить аналіз суб’єктів політичного простору і стратегій політичних акторів (Denysenko, 2013).

Для вітчизняної дослідницької практики характерне розуміння простору переважно 3 фізикалістської точки зору, тобто визначення політичного простору у взаємозв'язку з фізичним простором або територією, вивчення політичних процесів в межах певної території, іiі економіко- і 
соціально-географічних характеристик. Даний підхід обмежує пізнавальні можливості дослідника і призводить до поверхневого розуміння того, що являє собою політичний простір.

Метою статті $є$ розгляд та теоретичний аналіз основних положень сучасної теорії політичного простору.

Виклад основного матеріалу. Під впливом глобалізаційних процесів і розвитку технологій сучасний політичний простір якісно змінився. Вчені, що займаються його дослідженням, відзначають появу нових суб'єктів політики, здатних поширювати свою владу і вплив, виходячи за межі кордонів держав. Розвиток системи комунікацій і інформаційних технологій формує новий, інформаційний рівень політичного простору.

Політичний простір доцільно розглядати як сферу здійснення політики, тобто певний вид соціальної діяльності, не обов'язково пов'язаний із державною владою. І хоча політика виступає в єдності трьох взаємопов’язаних аспектів - як сфера суспільного життя, як вид активності соціальних суб’єктів та як тип соціальних відносин, але на кожен із цих аспектів впливають певні чинники, які й роблять політичний простір власне політичним.

Політичний простір, як і політика, обумовлюється трьома головними властивостями:

1) універсальністю, всеохоплюючим характером, здатністю впливати на всі сфери життя, елементи суспільства, відносини, події;

2) включеністю, тобто, можливістю безмежного проникнення в усі сфери життя;

3) атрибутивністю - здатністю поєднуватися 3 неполітичними суспільними явищами, відносинами та сферами (Burde, 1993).

Політичний простір визначає форму влади, їі організацію і побудову, межі владного впливу. Процес здійснення влади в політичному просторі нерозривно пов'язаний 3 питанням про роль індивідів, характером їх взаємодії в політичному процесі (Voronianskyi, 2014). 
Політичний простір можна представити в якості однієї з проекцій політики на область відносин, які складаються між різними суб'єктами 3 приводу влади. Простір виступає регулятором відносин груп та індивідів, областю взаємодій груп інтересів на перетині «горизонтальних» i «вертикальних» відносин.

Існуюча необхідність реорганізації простору-поля вимагає розширення кордонів світу політичного, появи нових інститутів і організацій. Перехід від класової суб’єктності індустріального суспільства до фрагментованої декласованої суб'єктності постіндустріалізму і викликана цим трансформація владних відносин (Voronianskyi, 2019) обгрунтовують необхідність нової концептуалізації політичного простору. Горизонтальної моделі соціальної комунікації, що складаються в нових умовах, обумовлюють первинність індивідів перед державою в здійсненні інституційних змін, визначаючи відповідні параметри політичного простору i політичної конкуренції індивідів, їх доступ до участі в політичних обмінах на різних рівнях.

Таким чином, нова концептуалізація політичного простору виникає як відповідь на необхідність зберегти керованість соціально-політичними процесами, що викликають ефект емансипації індивідів в ситуації наростаючої невизначеності. Новий образ політичного простору складається в умовах тимчасового розпаду соціальних зв’язків, викликаного дезорганізацією соціальних структур. У контексті процесу соціальної трансформації політичний простір визначається як функціональна система відкритого типу, що забезпечує реорганізацію соціального цілого за допомогою інституційного впорядкування інтеракцій індивідів. У результаті складається новий інституційний порядок, опосередкований формальними інститутами, що акумулюють культурно-історичні аспекти попереднього розвитку. Нова інституційна структура відображає цінності i знання, сформовані в ході історичного розвитку суспільства, які за допомогою символізації зберігаються в процесі еволюції політичного простору.

Таким чином, сучасний політичний простір формують інституційно 
регульовані взаємодії індивідів, що дозволяє уявити політичний простір як конструкт, де провідну роль відіграє символічний ресурс. Символізація пов’язує формальні і неформальні інститути, створює єдину систему для політичних обмінів, універсалізує канали комунікації (Voronianskyi ta Zaionchkovskyi, 2018).

Роль символічного ресурсу полягає в побудові нового образу політичного простору відповідно до змін потенціалу політики, меж можливого в політичному дії, характеру соціальних взаємодій. За допомогою механізмів символізації процеси, які самі по собі не мають політичного сенсу i змісту, набувають статусу політичних. При цьому неполітичні процеси, потрапляючи в сферу політики, стають предметом політичних обмінів, володіння якими стає запорукою зростання капіталізації індивіда в політичному просторі (Voronianskyi, 2012).

Використання інструментів символічної політики в публічному просторі може нести як позитивні риси, до яких можна віднести політичну освіту громадян, консолідацію суспільства, артикуляцію громадських інтересів тощо, так i негативні, набувати характеру маніпуляції i використовуватися, наприклад, для формування територіальної ідентичності у індивідів.

Інституційні аспекти політичного простору проявляються в його структуруванні, диференціації на окремі елементи. Функціонування громадських і політичних інститутів в політичному просторі залежить від особливостей середовища. Перенесення інститутів 3 одного політичного простору в інше супроводжується їх трансформацією за допомогою адаптації до особливостей системи (Zaionchkovskyi ta Osipov, 2019).

У дослідницькій літературі існує різне, але не суперечливе, розуміння того, яким чином організована структура політичного простору.

Політичний простір складається з ряду підструктур, що представляють собою, відповідно до П. Бурдьє, «сукупність об’єктивних відносин сил, які нав’язуються всім, хто входить в це поле» (Burde, 1993). Виходячи з цього, 
політичний простір можна розглядати як поле розгортання політичних акторів, втілення їх політичних практик.

В якості основних структурних елементів політичного простору дослідники виділяють політичні інститути i політичних акторів, що знаходяться в постійній взаємодії і взаємовпливі. В якості важливого структурного елементу політичного простору $є$ як формальні, так i неформальні політичні інститути, при посиленні ролі останніх. Сучасні соціально-політичні системи є більш відкритими, значення неформальних практик посилюється. Інститути визначають принципи політичних обмінів, доступ до влади, закріплюють розподіл ресурсів, соціальні ролі тощо (Voronianskyi, 2014). Найбільш активно на політичне життя суспільства впливають економічний і соціальний стан як державного, так і міжнародного порядку. Особливо важливими детермінантами політики $\epsilon$ економічні інтереси або інтереси власності, а також - інтереси певних соціальних груп щодо захисту та збереження свого владного статусу.

Велике значення в дослідженнях політичного простору має питання про його межі. Як фактори, що визначають межі політичного простору, доцільно розглядати процеси політизації інших сфер життєдіяльності соціальних систем і процеси деполітизації політичного простору. Подібний підхід є класичним і пов’язаний зі зміною розміру політичної сфери, пї поширенням на неполітичні відносини. Представляючи собою діалектичну єдність, дані процеси визначають умовність і нестійкість кордонів політичного простору. Таким чином, посилення процесів політизації економічного і соціокультурного простору відбувається в кризових ситуаціях функціонування соціальних систем, що призводить до розширення кордонів сфери політичного, i, навпаки, деполітизація політичних процесів i феноменів, характерна для періоду стабільного розвитку суспільства, веде до обмеження політичного простору. Процесу політизації соціальної сфери і, як наслідок, розширення меж політичного простору сприяє кризовий стан економіки країни. Звідси політичний простір доцільно розглядати як 
відкриту i нестійку систему, на функціонування якої великий вплив здійснюють зовнішні фактори.

\section{Висновки i перспективи подальших досліджень. Концепт} політичного простору несе в собі високий науковий потенціал, оскільки політичний простір має велике значення для сучасної політики, багато в чому визначає хід і характер розвитку держави, особливості культури і менталітет народу. політичний простір $€$ не лише середовищем здійснення різноманітних форм політичного життя чи конфігурація кордонів, а й середовищем спілкування і контактних зв’язків, що виникають у процесі політичної діяльності. Політичний простір як різновид простору суспільного - це, у свою чергу, насамперед сукупність політичних правил і інститутів, яким підпорядковує своє життя певне людське співтовариство. Зв’язки між людьми і політичними інститутами в рамках єдиного політичного простору продиктовані принципами, нормами та цінностями. Цілі людської діяльності відображають притаманні саме йому смисли, значення і розуміння.

\section{ЛІТЕРАТУРА}

1. Бурдье, П., 1993. Сочиология политики. Перевод с французкого Н. А. Шматко. Москва: Socio-Logos.

2. Воронянський, О. В. та Зайончковський, Ю. В., 2018. Політична філософія в умовах кризи традиційної методології: глухий кут чи гносеологічний прорив. Гуманітарний часопис, 3, с. 39-51.

3. Воронянський, О. В., 2012. Політична трансформація в контексті проблеми перерозподілу ресурсів. Вісник Харківського національного університету імені В.Н. Каразіна. Питання політології, 20(1007), с. 51-57.

4. Воронянський, О. В., 2014. Політичні інститути: механізм формування в конкурентному середовищі. Сучасне суспільство: політичні науки, сочіологічні науки, культурологічні науки, 1, с. 15-28.

5. Воронянський, О. В., 2019. Проблеми трансформації політичної суб'єктності в постіндустріальному суспільстві. Сучасне суспільство: політичні науки, соиіологічні науки, культурологічні науки, 2(18), с. 3747.

\section{REFERENCES}

1. Burde, P., 1993. Sociologiya politiki. Perevod s francuzkogo N. A. Shmatko. Moskva: Socio-Logos

2. Voronianskyi, O. V. ta Zaionchkovskyi, Yu. V., 2018. Politychna filosofiia v umovakh kryzy tradytsiinoi metodolohii: hlukhyi kut chy hnoseolohichnyi proryv. Humanitarnyi chasopys, 3, s. 39-51

3. Voronianskyi, O. V., 2012. Politychna transformatsiia $\mathrm{V}$ konteksti problemy pererozpodilu resursiv. Visnyk Kharkivskoho natsionalnoho universytetu imeni V.N. Karazina. Pytannia politolohii, 20(1007), s. 51-57.

4. Voronianskyi, O. V., $2014 . \quad$ Politychni instytuty: mekhanizm formuvannia $\mathrm{v}$ konkurentnomu seredovyshchi. Suchasne suspilstvo: politychni nauky, sotsiolohichni nauky, kulturolohichni nauky, 1, s. 15-28.

5. Voronianskyi, O. V., 2019. Problemy transformatsii politychnoi subiektnosti V postindustrialnomu suspilstvi. Suchasne suspilstvo: politychni nauky, sotsiolohichni nauky, kulturolohichni nauky, 2(18), s. 3747. 
6. Денисенко, I. Д., 2010. Проблемне поле методології політичних досліджень. Вісник Національної юридичної академії України імені Ярослава Мудрого. Філософія, філософія права, політологія, соиіологія, 5 , c. 116-124.

7. Денисенко, І. Д., 2013. Соціальні мережі в контексті соціокультурного підходу: евристичний потенціал дослідження. Вісник ХНПУ імені Г.С. Сковороди «Філософія», 40, с. 22-28.

8. Денисенко, І. Д., 2015. Теорія соціального простору: евристичний потенціал щодо соціально-політичних досліджень. Сучасне суспільство: політичні науки, сочіологічні науки, культурологічні науки, 2(2), с. 27-37.

9. Зайончковський, Ю. В. та Осіпов, О.М. 2019. Неокорпоративізм в умовах глобалізації: досвід Західної Європи. Сучасне суспільство: політичні науки, сочіологічні науки, культурологічні науки, 2(16), c. 98-107.
6. Denysenko, I. D., 2010. Problemne pole metodolohii politychnykh doslidzhen. Visnyk Natsionalnoi yurydychnoi akademii Ukrainy imeni Yaroslava Mudroho. Filosofiia, filosofiia prava, politolohiia, sotsiolohiia, 5, s. 116-124.

7. Denysenko, I. D., 2013. Sotsialni merezhi v konteksti sotsiokulturnoho pidkhodu: evrystychnyi potentsial doslidzhennia. Visnyk KhNPU imeni H.S. Skovorody «Filosofiia», 40, s. 22-28.

8. Denysenko, I. D., 2015. Teoriia sotsialnoho prostoru: evrystychnyi potentsial shchodo sotsialno-politychnykh doslidzhen. Suchasne suspilstvo: politychni nauky, sotsiolohichni nauky, kulturolohichni nauky, 2(2), s. 27-37.

9. Zaionchkovskyi, Yu. V. ta Osipov, O. M. 2019. Neokorporatyvizm v umovakh hlobalizatsii: dosvid Zakhidnoi Yevropy. Suchasne suspilstvo: politychni nauky, sotsiolohichni nauky, kulturolohichni nauky, 2(16), s. 98-107.

\section{Інформація про авторів}

Кошкіна Ольга Ігорівна - доцент кафедри суспільно-гуманітарних дисциплін Харківського національного університету будівництва та архітектури; e-mail: styader@gmail.com; ORCID: http://orcid.org/0000-0003-1123-5411.

Моіссєва Наталія Іванівна - доктор філософії, доцент, професор кафедри ЮНЕСКО «Філософія людського спілкування» та соціально-гуманітарних дисциплін Харківського національного технічного університету сільського господарства імені Петра Василенка; еmail: ntusgunesco96@gmail.com; ORCID: http://orcid.org/0000-0001-6349-7892.

Стаття надійшла до редакції: 06.11.2019 р. Прийнята до друку: 29.11.20119 р. 